\title{
Instructional Design: Increasing the Effectiveness of Bibliographic Instruction
}

\section{Marian I. Miller and Barry D. Bratton}

Public service librarians frequently offer library instruction to academic library users. Despite good intentions, this instruction is often hampered by insufficient planning for the particular situation. The instructional design process provides a systematic method to prepare and present bibliographic instruction both effectively and efficiently by focusing on five essential elements. Those who use instructional design report favorably on the results of this systematic approach.

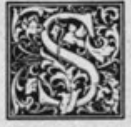

ettings may vary for public service librarians in academic libraries, but patrons' problems are similar. For example:

- A student asks the location of learning disabilities journals to find articles on minimal brain dysfunction for which she has no references. She does not know that periodical indexes can greatly simplify her information search.

- A disconcerted patron, accustomed only to the Dewey Decimal Classification System, cannot find the books for which he has call numbers. He has copied the numerals for the Library of Congress call numbers but has omitted the letters.

Patrons' consternation with such problems can turn to frustration for the librarian. Basic unfamiliarity with library services may be responsible. Opportunities for formal instruction are frequently limited in academic library settings. Even when the opportunity exists, the instruc- tion may not be as effective as the librarian would hope. Quality library instruction could benefit many academic library patrons and in turn ease the burden on the library staff.

Keith Cottam and Connie Dowell have cited the contribution of instructional design in the development of bibliographic instruction. ${ }^{1}$ This article introduces readers to instructional design as a means for designing library instruction.

Instructional design is a systematic methodology for creating educational programs that achieve the desired objectives. The five key elements considered when designing programs are the learners, the learning objectives, the subject content, the teaching methods, and the evaluation of learning.

\section{THE LEARNERS}

Who are the learners, and what are their educational needs? Are they freshmen and, therefore, new to the library and to 
college life altogether? Are they nontraditional students who have been away from a formal learning environment for years? Are they international students for whom there are many cultural adjustments? Are they faculty members new to the campus or unfamiliar with the library resources? The learner must be the constant focus in the instructional design process.

Effective instruction is based on an educational need, that is, the discrepancy between what the learners now know and what they ideally should know. For example, freshmen may not be able to find books on their subjects because they do not know how to use the Library of Congress subject headings when searching the card catalog. They would be more successful if they knew standardized terms exist in Library of Congress Subject Headings. Do students lack skills in using periodical indexes? Are they unfamiliar with the physical arrangement of the library? Are basic library terms a barrier for international students? These are examples of instructional needs and should be considered in planning instruction. To be effective, library instruction must be prepared conscientiously, with a detailed consideration of the audience.

Iowa State University librarians and instructional designers developed instruction for freshmen who were primarily from rural backgrounds, had limited library experiences, and were unfamiliar with the facilities of a large state university library by taking into account those characteristics and designing the program appropriately. ${ }^{3}$ Likewise, at the University of Houston-University Park, librarians designed new library instruction for nontraditional students. Working with an instructional design consultant, the librarians identified learning needs such as interpreting citations, finding statistics, and understanding computer searching. ${ }^{4}$

Persons planning library instruction frequently try to teach too much in one session. At Brigham Young University, librarians recognized in their philosophical criteria the importance of limiting instruction to educational needs. ${ }^{5}$ Teaching material that is not essential to students' educational needs can overburden the learner and can lead to frustration for both student and instructor. Instructional design helps to focus on specific learners' needs.

\section{THE OBJECTIVES}

Objectives have been part of educational jargon for years. In instructional design, learning objectives play a vital role in building the overall framework.

Objectives build toward a goal. For example, an instructional goal could be to acquaint the students with basic resources in a particular library. The following objective, when mastered by the students, might help them reach this goal.

From a list of ten authors, subjects, and titles, the students will be able to determine whether to use the author/title section or the subject section of the card catalog.

This objective provides the designer of the instruction with a tool for focusing on the relevant content and for evaluating the extent to which learning is achieved, all leading toward the stated goal. ${ }^{6}$ Working toward the above objective encourages an instructor to ask, Can the students distinguish between a subject and a title? If the answer is no, additional instruction will be needed to teach the difference as well as the purposes of the respective sections. If the answer is yes, the need is for instruction in the use of the two sections of the catalog.

\section{SUBJECT CONTENT}

Subject content should be carefully analyzed when instruction is designed. Recognizing objectives can be a means for dissecting content. For example, in teaching the use of Readers' Guide, one should ask questions such as: What does $R G$ do and how? When should it be used? When should it not be used? Objectives help subject experts see their respective content areas through the eyes of novices. Once objectives have been determined for specific content areas, content should continue to be scrutinized. This will weed nonessential information that overwhelms learners and hampers the learning process. As Wilburn suggests, instructional material must be pared to the essential minimum.? 
The order in which information is presented makes a difference in the success of the learning experience. For example, in order for a student to locate a book, the normal procedure is to begin at the card catalog or public access terminal and then retrieve the book from the stacks. A student unfamiliar with a particular classification system might be better served by an introduction to shelving order of those call numbers before working directly with interpreting catalog entries. Someone with little or no knowledge of periodical indexes might understand citations better through examination of the parts of an entry in an actual journal rather than through explanation of entries in periodical indexes.

\section{THE TEACHING METHODS}

Once objectives are developed and content is analyzed, potential teaching methods and resources are considered. For example, what facilities and equipment are available? Are personnel trained to use a specific method? If not, is training to do so feasible? What is the budget for developing and implementing new instruction? What are the time constraints? How many learners will be receiving this instruction at any given time? What methods would be most effective with this particular group of learners? These are a number of the questions to be answered when choos- ing the most appropriate instructional methods.

Choosing a teaching method implies that the instructional librarian is skilled in a variety of methods. Flexibility in methods allows the teacher to adapt to different learner characteristics and teaching objectives.

What media should be used? is frequently asked as library instruction is planned. Larry Hardesty addresses the subject by emphasizing that the choice of medium to the instruction (whether it be videotape, live lecture, $\mathrm{CAI}$, group discussion, etc.) should be dictated by the objectives, learner characteristics, and resources. $^{8}$

\section{EVALUATION}

Evaluation, the fifth element in the instructional design process, applies to two areas: the learners and the program. Questions typically asked when focusing on the learners include: What do they know before instruction? How are they progressing? What have they learned from the instruction?

Other questions focus on the program. Are the methods effective with this group? Are all of the objectives being met? Is this program meeting the learning needs of the students? Is the program cost-effective?

Evaluation is an ongoing process when

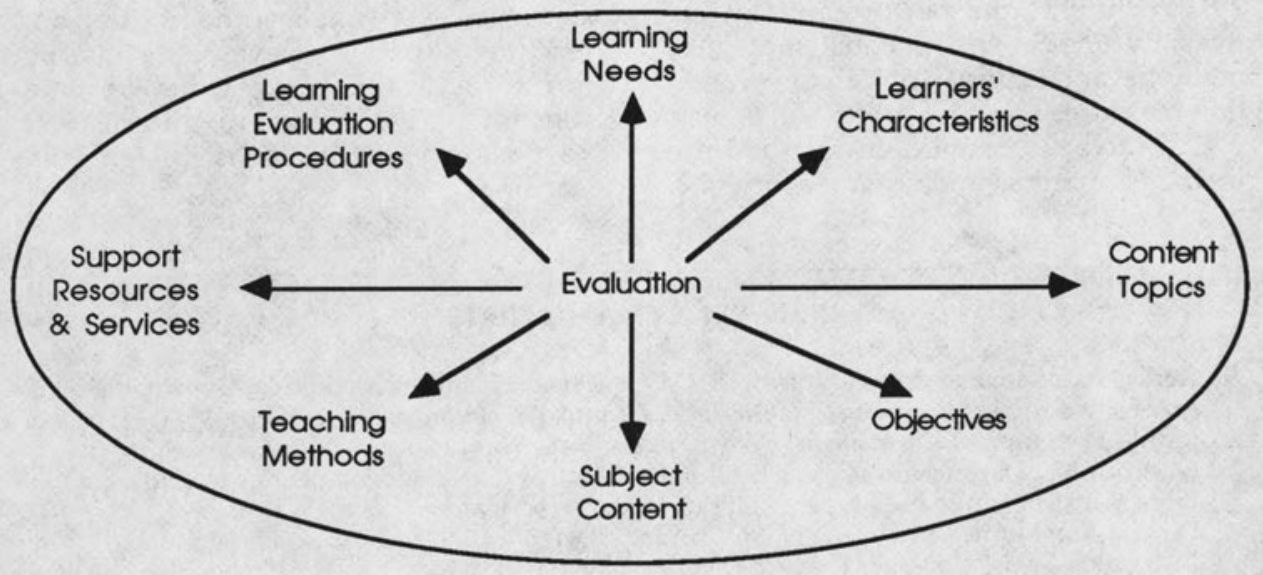

FIGURE 1

Kemp's (1985) Instructional Design Model 
designing instruction. Methods of evaluation vary from formal testing to surveying participants. Information is collected as a program is developed and implemented, and revisions are made based upon evaluations; these revisions are in turn evaluated. This cyclical nature of evaluation continues until the designer is satisfied with the efficiency and effectiveness of the program.

\section{"Instructional design models have been developed to serve as 'check- lists' for librarians who plan instruc- tion."}

\section{INSTRUCTIONAL DESIGN MODELS}

Instructional design models have been developed to serve as "checklists" for librarians who plan instruction. Some models are intended for use specifically in library instruction. For example, Cottam's model for bibliographic instruction was developed for academic libraries, using the concepts described above. The model consists of seven phases:

1. Identify a presumed instructional need.

2. Analyze, describe, and define the need.

3. Formulate the performance objectives; outline the instructional strategies, methods, and material; design the evaluation measures.

4. Develop, produce, or compile the methods, material and other resources.
5. Deliver the instruction.

6. Analyze the evaluation data.

7. Reprocess.'

Some models are useful for a variety of disciplines. One example, developed by Jerrold Kemp, advocates the assessment of learning needs, evaluation of the learners' characteristics and current level of knowledge, careful selection of content topics, development of learning objectives, analysis of subject content, selection of teaching methods resources based on available support services, and the preparation of learning evaluation procedures. ${ }^{10}$ This model, shown in figure 1 , can assist with all types of bibliographic instructional design whether it be student orientation, staff training, or faculty instruction.

\section{CONCLUSION}

Learning can take place in a planned or an unplanned setting. Students can learn to use the library when they are presented library instruction prepared without the aid of instructional design. However, since more formal library instruction opportunities have time constraints and educational accountability applies to bibliographic instruction, persons responsible for such instruction within academic libraries should draw on the benefits of instructional design.

The instructional design process encourages planners of library instruction to scrutinize every angle of the learning and teaching situation. Developing instruction through this process may be timeconsuming, but experience and research have shown that it results in significant learning.

\section{REFERENCES AND NOTES}

1. Keith M. Cottam and Connie V. Dowell, "A Conceptual Planning Method for Developing Bibliographic Instruction Programs," Journal of Academic Librarianship 7:223-28 (Sept. 1981).

2. Jerrold E. Kemp, The Instructional Design Process (New York: Harper, 1985).

3. Gertrude N. Jacobson and Michael J. Albright, "Motivation via Videotape: Key to Undergraduate Library Instruction in the Research Library," Journal of Academic Librarianship 9:271 (Nov. 1983).

4. Patricia Ann Kenney and Judith N. McArthur, "Designing and Evaluating a Programmed Library Instruction Text," College \& Research Libraries 45:36 (Jan. 1984).

5. Marvin E. Wiggins, The Development of Library Use Instructional Programs," College \& Research Libraries 33:473-74 (Nov. 1972). 
6. Leslie J. Briggs, ed., Instructional Design: Principles and Applications (Englewood Cliffs, N.J.: Educational Technology Publications, 1977) p.57-62.

7. Barbara Love, "Library Instruction: Recreating the Image," College \& Research Libraries News 48:482 (Sept. 1987).

8. Larry Hardesty, Use of Media in Library Use Instruction (Bethesda, Md.: ERIC Document Reproduction Service, 1984; ED 261688 , IR 051 258).

9. Cottam and Dowell, "A Conceptual Planning Method," p.225.

10. Kemp, The Instructional Design Process, p.11. For other models that may be useful in bibliographic instruction, see Briggs, Instructional Design, p.12 and Walter Dick and Lou Carey, The Systematic Design of Instruction (Glenview, Ill.: Scott, Foresman, 1985), p.2-7. 


\section{Come to Salt Lake City \\ for the \\ Fifth National Conference and Exhibition \\ of the \\ American Association of School Librarians \\ October 18-22, 1989}

Join more than 3,500 of your colleagues from across the country at the Conference that will offer you intellectual stimulation and professional growth through seminars, workshops and programs.

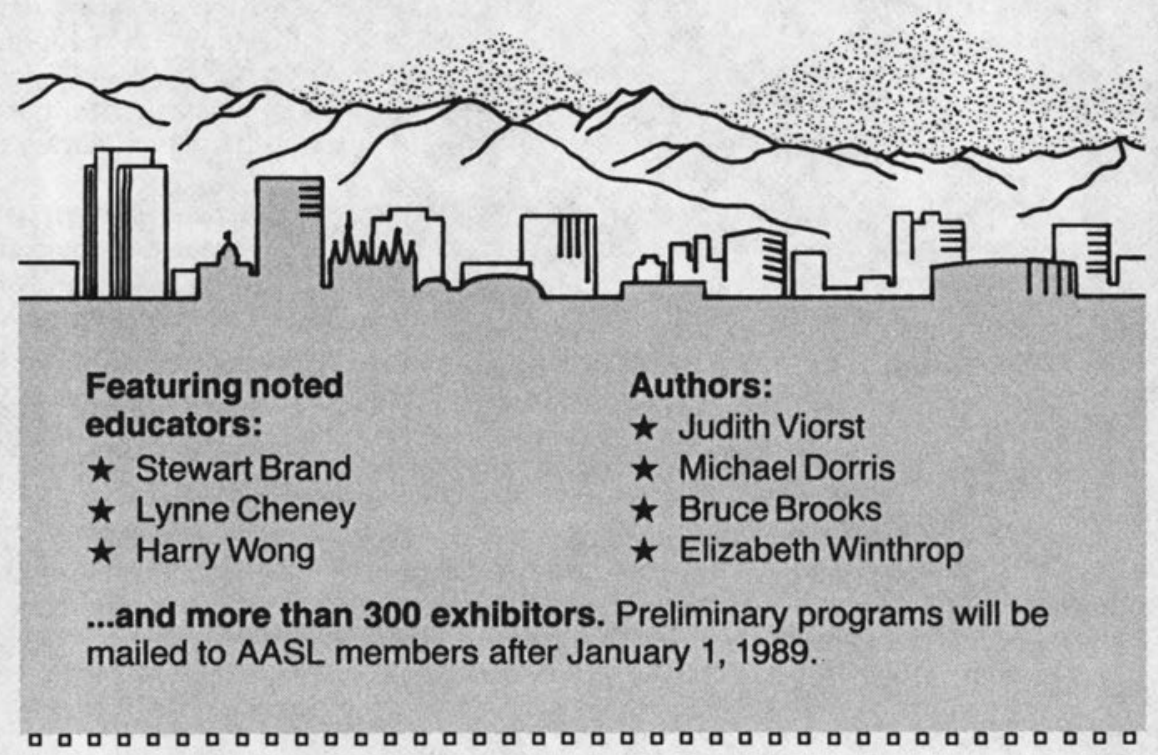

Access to Send more information on program exhibiting

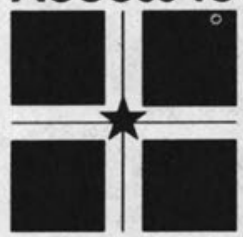

Excellence

Name

Address

City State Zip

Send to: American Association of School Librarians, 50 East Huron St., Chicago, IL 60611, (312) 944-6780. 